\title{
Long-term Results of Patients with Testicular Tumors Undergoing Testis Sparing Surgery: A Single-center Experience
}

\author{
Testis Koruyucu Cerrahi Uygulanan Testis Tümörlü Hastaların Uzun Dönem Sonuçları: \\ Tek-merkez Deneyimi
}

\author{
(D) Fuat Kızılay1, (D) Serdar Kalemci¹, (D) Adnan Şimşir¹, (D) Hamed Jafarzadeh Andabil2, (D) Banu Sarsık², (D) Sait Şen², (D) Çağ Çal1, \\ (D) İbrahim Cüreklibatır1 \\ 1 Ege University Hospital, Department of Urology, Izmir, Turkiye \\ 2Ege University Hospital, Department of Pathology, İmir, Turkiye
}

\section{What's known on the subject? and What does the study add?}

Testis-sparing surgery (TSS) is a treatment modality that can be applied to selected patients with testicular tumors. Although similar oncologic results and favorable functional outcomes were reported in many series, there is no clear consensus on which patients and how this method will be applied. In this study, we evaluated the results of TSS cases performed in our clinic and showed that the method provided favorable long-term oncologic results without leading to significant complications. We underline that this technique should be performed with frozen section analysis in patients with a solitary testicular mass or in patients with bilateral testicular masses.

\begin{abstract}
Objective: To determine the clinicopathologic and oncologic outcomes of testis-sparing surgery (TSS) by evaluating the data of patients who underwent TSS in our clinic.

Materials and Methods: A total of 24 patients (27 testes) who underwent TSS in the last 16 years were included in the study. All the patients presented with a solitary testicular mass or bilateral testicular mass. Preoperative tumor markers were investigated and scrotal ultrasonography was performed in all patients. Surgery was performed with inguinal incision, temporary clamping of the spermatic cord and frozen section analysis (FSA) of the lesion. Intraoperative data, histopathological findings, and recurrence status were analyzed.

Results: The mean follow-up period was 96 months. The mean age of the patients was 29.7 (18-66) years. The mean tumor diameter was 11 mm (2-18). TSS was performed bilaterally in 3 patients and unilaterally in 24 patients. According to the final pathology report, 18 (66.7\%) of the masses were benign and 9 (33.3\%) were malignant. Intraoperative FSA was performed in 17 patients (70.8\%). FSA revealed malign histopathology in 6 patients and complementary orchiectomy was performed in 4 of these patients. 14 patients (51.9\%) were detected to have positive surgical margins. Two of these patients had seminoma diagnosis and radical orchiectomy was performed due to recurrence on follow-up in these patients. TSS was performed in all patients without any significant intra-postoperative complications.

Conclusion: TSS may have significant functional and cosmetic benefits without worsening oncologic results in appropriately selected patients. Keywords: Testicular tumor, Testis-sparing surgery, Orchiectomy, Frozen section, Organ-sparing treatment, Positive surgical margin
\end{abstract}

Öz

Amaç: Kliniğimizde testis-koruyucu cerrahi (TKC) uygulanan hastaların verilerini değerlendirerek bu yöntemin klinikopatolojik ve onkolojik sonuçlarını belirlemek.

Gereç ve Yöntem: Son 16 yılda TKC uygulanan toplam 24 hasta (27 testis) çalışmaya alındı. Tüm hastaların soliter testisinde kitlesi veya bilateral testiküler kitlesi mevcuttu. Tüm hastalarda preoperatif tümör belirteçleri bakıldı ve skrotal ultrasonografi yapıldı. Cerrahi işlem, inguinal insizyon, spermatik kordun geçici olarak klemplenmesi ve lezyonun frozen kesit analizi (FKA) ile yapıldı. İntraoperatif veriler, histopatolojik bulgular ve nüks durumu analiz edildi.

Correspondence: Fuat Kızılay MD, Ege University Hospital, Department of Urology, İzmir, Turkiye

Phone: +90 5325800685 E-mail: fuatkizilay@gmail.com ORCID-ID: orcid.org/0000-0003-1856-0404

Received: 18.10.2018 Accepted: 24.11.2018

Cite this article as: Kızılay F, Kalemci S, Şimşir A, Andabil HJ, Sarsık B, Şen S, Çal Ç, Cüreklibatır i. Long-term Results of Patients with Testicular Tumors Undergoing Testis Sparing Surgery: A Single-center Experience. J Urol Surg 2019;6(2):93-99.

๑Copyright 2019 by the Association of Urological Surgery / Journal of Urological Surgery published by Galenos Publishing House. 
Bulgular: Hastaların ortalama takip süresi 96 aydı. Hastaların yaş ortalaması 29,7 (18-66) idi. Ortalama tümör çapı 11 mm (2-18) idi. TKC, 3 hastada bilateral olarak ve 24 hastada tek taraflı olarak uygulandı. Son patoloji raporuna göre kitlelerin 18'i $(\% 66,7)$ benign, 9'u $(\% 33,3)$ malign histopatolojiye sahipti. İntraoperatif FKA, 17 hastada $(\% 70,8)$ gerçekleştirildi. FKA uygulanan altı hastada malign histopatoloji mevcuttu ve bu hastaların 4 'ünde tamamlayıcı orşiektomi yapıldı. Cerrahi sınır, 14 hastada $(\% 51,9)$ pozitifti. Bu hastaların ikisinde seminom teşhisi mevcuttu ve bu hastalarda takipte nüks nedeniyle radikal orşiektomi yapıldı. TKC, tüm hastalarda anlamlı bir intra-, postoperatif komplikasyon olmaksızın gerçekleştirildi.

Sonuç: TKC, uygun hastalarda onkolojik sonuçları kötüleştirmeden önemli fonksiyonel ve kozmetik faydalar sağlayabilir.

Anahtar Kelimeler: Testis tümörü, Testis koruyucu cerrahi, Orşiektomi, Frozen kesit, Organ koruyucu tedavi, Pozitif cerrahi sınır

\section{Introduction}

Testicular germ cell tumors (GCTs) constitute $2 \%$ of all male malignancies and they are the most common solid malignant neoplasms in men aged 15-35 years. Three-ten new cases occur per 100.000/men per year in Western countries (1). Its incidence has increased in recent years, especially in industrialized countries $(1,2)$. Men with cancer in one testis are at risk for developing cancer in the other. The incidence of contralateral testicular cancer is between 3\% and 5\% (3).

Radical orchiectomy is the recommended standard approach today in patients with bilateral testicular tumors or with solitary testicular tumors, as in patients with normal contralateral testis. However, in this case, infertility, androgen insufficiency and psychological stress are inevitable (4). All these possible side effects, increased number of benign testicular masses, and increase in the number of asymptomatic, non-palpable masses detected with the widespread use of testicular ultrasound have called the necessity of taking the entire testicle even in apatient with a normal contralateral testis in question (5). The reliability of frozen section analysis (FSA) in the differential diagnosis of benign and malignant masses has also strengthened the hand of the testis-sparing surgery (TSS), which is quite advantageous in terms of functional, cosmetic and psychological aspects (6).

In 1982, Seppelt first performed TSS for metachronous contralateral seminoma after radical orchiectomy. Six weeks after surgery, the testis was removed, and the remaining parenchyma showed no tumor tissue (7), and 2 years later, this approach was labeled as un-orthodox method by Richie (8). TSS then started to be performed at increasing frequency for suspected metachronous GCTs and for masses in solitary testis. However, TSS might be used in men with normal contralateral testis with small, non-palpable lesions thought to be benign detected with widespread use of testicular ultrasound (9).

After the publication of the first pioneering study by Heidenreich et al. (10) in 1995, the German Testicular Cancer Working Group carried out extensive studies in the international arena (11). Although currently the only definitive indications for TSS are histologically proven benign testicular masses, it continues to be an important alternative to radical orchiectomy for patients with bilateral testicular or solitary testicular masses with significant psychological and endocrinological advantages and long-term disease-free survival. The increase in the detection of incidental testicular masses has also brought innovations to the surgical techniques and led to the questioning of the indications for TSS. Asymptomatic, small-volume testicular tumors are frequently misinterpreted as GCT and inguinal orchiectomy is performed. The European Association of Urology guidelines recommend TSS for small, ultrasound-detected, non-palpable intraparenchymal lesions (12).

In this study, we reviewed the testicular cancer cases we have treated in our clinic for sixteen years, and we performed the clinicopathological and oncological analysis of patients who underwent TSS during this period.

\section{Materials and Methods}

\section{Patient Selection and Preoperative Preparation}

Of the 727 orchiectomy cases in our clinic between the years 2000 and 2017; 27 (3.71\%) TSSs of 24 cases were included in the study. All patients had solitary testicular tumors or bilateral testicular tumors. Radical or partial orchiectomy options were offered to patients and written informed consent was taken from patients who underwent TSS. Serum tumor markers, including $\alpha$-fetoprotein, lactate dehydrogenase and $\beta$ human chorionic gonadotropin, were measured preoperatively in all patients. Preoperative ultrasonography was performed to evaluate lesion size, volume, sonographic characteristics of the mass and contralateral testis in all patients. Preoperative cryopreservation was recommended to all patients due to fertility problems that may occur in the postoperative period and the procedure was performed in appropriate patients.

\section{Operative Technique}

As in radical orchiectomy, the surgery was started with inguinal incision. The spermatic cord was dissected, dislodged and held with a soft vascular clamp or rotated with a tourniquet. The testis was delivered and the gubernaculum testis was clamped or cut off. The testis was isolated outside the operation field with the help of testicular compresses to prevent possible tumor seeding or wound contamination during excision of the mass. Tunica 
vaginalis was incised and testis was palpated. Non-palpable masses were detected by intraoperative ultrasonography and the area adjacent to the lesion was marked with a thin caliber needle. The mass was excised and sent to a FSA with a 2-5 $\mathrm{mm}$ normal parenchymal tissue around the mass. After excision, the complete excision of the mass was controlled by ultrasonography. If the mass was benign according to FSA result, the parenchyma was washed with isotonic and the clamp on the spermatic cord was opened and after the hemostasis was achieved, the tunica albuginea was closed with a running 4-0 or 5-0 absorbable suture. The patients was discharged on the day of operation or on the first postoperative day.

\section{Follow-up of the Patients and Analysis of the Data}

Follow-up of the patients was performed with periodic physical examination, analysis of the tumor markers and scrotal ultrasonography. The patients were taught self-examination and regular applications were recommended; the patients were assessed with the proper tests in the presence of any suspicious finding.

Demographic characteristics of patients, and prognostic factors, such as and type of the lesion in benign cases and tumor size, tumor type, and metastasis status in malign cases were evaluated. All patients provided written informed consent before the surgery for the use of the collected data at any time. The principles of the Helsinki Declaration were followed during the study, and the confidentiality of the patients' data was guaranteed. Descriptive statistics were used for the analysis of the data.

\section{Statistical Analysis}

Prognostic factors such as demographic data of cases, characteristics and types of lesion in benign cases and tumor size, tumor type, and metastasis status in malign cases were evaluated. All patients had given written informed consent before the surgery for giving permission for the use of the collected data at any time. The principles of the Helsinki Declaration were followed during the study, and the confidentiality of the patients' data was guaranteed. Descriptive statistics were used for the analysis of the data.

\section{Results}

The mean age of the patients was 29.7 (18-66) years. Partial orchiectomy was performed in $3(12.5 \%)$ of the cases bilaterally and in $21(87.5 \%)$ unilaterally. The mean tumor diameter was 11 (2-18) $\mathrm{mm}$. Demographic data and tumor characteristics of the patients are summarized in Table 1.

In 18 patients, scrotal ultrasonography was performed for other reasons and the testicular mass was diagnosed incidentally.
While 4 patients had testicular mass complaints, 2 patients had only testicular pain.

Ultrasonographic findings were hypoechoic, heterogeneous and calcific lesions. The most common ultrasonographic finding in 21 of 24 patients was a hypoechoic nodule. The presence of a hypoechoic structure and no or very little blood flow were strong predictors of benign nature of the mass.

In one of the bilateral cases, the morphological tumor pattern was embryonal and benign non-GCTs in the other two. In our series, all of the masses were smaller than $18 \mathrm{~mm}$ and $66.7 \%$ $(n=18)$ of them were benign. An interesting finding of our study was that 9 masses (33.3\%) were malignant although the size of all masses was less than $18 \mathrm{~mm}$. In 17 cases (70.8\%) intraoperative FSA was performed. Of these, 6 had a malignant GCT diagnosis and 4 had a complementary orchiectomy. $37.5 \%$ of the tumors $(n=9)$ were found to be GCT, 4-seminoma, 3-mixed GCT and 2 were embryonal carcinoma. Six of nine patients with malignant histopathology were found to have germ cell neoplasia in situ (GCNIS) in final histopathological examination. Adjuvant local radiotherapy with a dose of $20 \mathrm{~Gy}$ in $2 \mathrm{~Gy}$ fractions was given to these patients. The remaining

Table 1. Demographic data and tumor characteristics of the patients

\begin{tabular}{ll}
\hline Variables & Value \\
\hline Patient & $24(100 \%)$ \\
\hline Age (years) & $29.7(18-66)$ \\
\hline Body mass index $\left(\mathrm{kg} / \mathrm{m}^{2}\right)$ & $22.8(18.1-37.6)$ \\
\hline Tumor diameter $(\mathrm{mm})$ & $11(2-18)$ \\
\hline Tumor side & $10(37 \%)$ \\
Left & $17(63 \%)$ \\
Right & $27(100 \%)$ \\
\hline Partial orchiectomy & $3(12.5 \%)$ \\
\hline Partial orchiectomy type & $21(87.5 \%)$ \\
Bilateral & $17(70.8 \%)$ \\
Unilateral & $14(51.9 \%)$ \\
\hline Intraoperative frozen section analysis & $13(48.1 \%)$ \\
\hline Surgical margin status & \\
Positive & $18(75 \%)$ \\
Negative & $4(16.7 \%)$ \\
\hline Indications of scrotal ultrasonography & $2(8.3 \%)$ \\
Other reasons & $21(87.5 \%)$ \\
Testicular mass & $1(4.2 \%)$ \\
Testicular pain & $2.3 \%)$ \\
\hline Ultrasonographic findings & \\
Hypoechoic & \\
Heterogeneous & \\
\hline Valcific & \\
\hline Valus are given & \\
\hline
\end{tabular}

${ }^{1}$ Values are given as mean (minimum-maximum) or number (percent) 
15 cases (62.5\%) had benign histopathology. The distribution of the tumor histopathology is shown in Table 2. Fourteen patients had positive surgical margins. Twelve of them had benign, and the other 2 cases had malignant GCT morphology (seminoma). Radical orchiectomy was performed after a recurrent mass was detected in these patients. Radical orchiectomy was required after 22 months in one of the patients and 28 months in the other. The mean follow-up period of the patients was $96.4 \pm 12.6$ months. According to the physical examination and scrotal ultrasound findings, all patients except these two were tumorfree.

We did not encounter any significant intra- or postoperative complications associated with surgery. The patients were discharged on the same day or 1 day after surgery. In the postoperative period, post-dural puncture headache was seen in 3 patients and these patients were re-hospitalized and discharged 1 day after appropriate treatment.

Table 2. The distribution of the tumor histopathology

\begin{tabular}{ll}
\hline Histopathology & Number \\
\hline Benign & 7 \\
Epidermoid cysts & 1 \\
Dermoid cyst & 2 \\
Adenomatoid tumors & 1 \\
Adrenocortical syndrome testicular & \\
tumor & 1 \\
Hemangioma & 4 \\
Sertoli cell & 2 \\
Leydig cell & $18(66.7 \%)$ \\
Total &
\end{tabular}

\begin{tabular}{ll}
\hline Malign & \\
Seminoma & 4 \\
Mixed GCT' & 3 \\
Embryonal carcinoma & 2 \\
Total & $9(33.3 \%)$ \\
\hline
\end{tabular}

GCT: ${ }^{1}$ Germ cell tumor

\section{Discussion}

Organ-sparing surgeries are now being used in many fields of oncological medicine, with the development of surgical techniques, without affecting long-term disease-specific survival and increasing morbidity due to treatment (13). Along with the developing technology, there has also been an awful change in the field of urological oncologic surgery. For example; nephron-sparing surgery has taken place in radical nephrectomies in nearly all appropriate renal tumors. This change has also manifested itself in testicular tumors and the indications of TSS have become questionable. Most nonpalpable lesions smaller than $25 \mathrm{~mm}$, defined as small testicular masses, have proven to be benign $(14,15)$. Radical orchiectomy may be an extra treatment for these masses and may have negative endocrine and psychological effects $(16,17)$.

According to classical knowledge, TSS is not indicated in cases where the contralateral testis is normal. German Cancer Study Group suggests that TSS is controversial in patients with normal contralateral testis and without mandatory indications (11). TSS may be performed in synchronous bilateral testicular tumors, metachronous contralateral tumors, and solitary testis tumors with normal preoperative testosterone levels if tumor volume is less than $30 \%$ of the testicular volume (18). A patient with a tumor in the solitary testis or bilateral testicles or a suspected strong benign lesion may be an eligible candidate for TSS $(19,20)$.

In patients who underwent TSS, a subject with a concern is that GCNIS foci remain in the testis. GCNIS can accompany up to $85 \%$ of cases (21). Biopsy with FSA may be helpful for this manner. In the 91-month median follow-up of 73 men who underwent TSS by the German Testicular Cancer Study Group, only 4 patients had local recurrence. Those four were untreated GCNISs (22). There are some authors suggesting adjuvant radiotherapy to all patients who underwent TSS whether the tumor histology is seminoma or non-seminoma, but the results of fertility and spermatogenesis of these patients are the major concerns. Therefore, this treatment has not become the gold standard method. Others argue that it is more appropriate to reserve this treatment when GCNIS is detected (20). We preferred local adjuvant radiotherapy in patients with only GCNIS in accordance with the generally accepted opinion. Our patients fertile ages and their desire to have children were important factors in this decision.

There are strong suggestions about the technique, postoperative treatment and follow-up as well as the indications of TSS. Testicular tumor size to be less than $20 \mathrm{~mm}$, clamping of the spermatic cord under cold ischemia, the biopsy of the tumor bed during surgery, postoperative radiotherapy to eradicate carcinoma in situ in the residue testicular tissue in order to avoid local recurrences and close monitoring of the patients are recommended (22). Metachronous testicular tumors are more common than synchronous tumors. However, the time interval between the first and second tumors is variable. It has been reported that the likelihood of malignancy increases in testicular masses greater than $2 \mathrm{~cm}$ and the probabilitiy of remaining adequate testicular parenchyma tissue decreases (23).

It has been reported that TSS has the potential to cause less fertility problems, hormonal insufficiency and psychosocial distress. There was no significant local and/or distant recurrence risk after TSS after medium and long-term follow-up (24). However, residual tumor is the most significant risk factor for 
local recurrence after TSS.

De Stefani et al. (25) found benign lesions in 91\% of patients with 23 small testicles treated with TSS. Malignant lesions were detected in 2 patients (9\%) in FSA. In both cases, the final pathology report was consistent with the seminoma. Radical orchiectomy was performed in these two patients. After a mean follow-up of $35 \pm 25$ months, all patients were tumor-free (25).

It has also been reported that FSA performed during TSS correctly detects all non-tumor lesions, but may fail at 3.5\% in tumor detection (26). This is quite a low rate and surgeons usually have no difficulty in making decisions thanks to the FSA's high diagnostic accuracy (27). Elert et al. (28) demonstrated that FSA distinguishes all benign and malign lesions in their 354 case series. Leroy et al. (29) have shown that the sensitivity of FSA in 15 cases is $81 \%$ for benign lesions and $100 \%$ for malign lesions. Connolly et al. (27) found 94\% positive predictive value and 93\% negative predictive value for malignancy in 80 patients. In our study, FSA was performed in 17 patients (70.8\%). Six of them were malign and four had undergone complementary orchiectomies. All the risks were commentated to these patients in the preoperative period who had not undergone orchiectomy, but they did not want to stay without testis and wanted to be followed-up. It should be kept in mind that FSA is a very difficult method for pathologists and these cases should be evaluated in centers which harbor experienced pathologists in uropathology field (29). In our study, all specimens were assessed by two experienced uropathologists. In our study, intraoperative ultrasonography was used perioperatively and it was confirmed that there was no tumor left behind. However, surgical margin positivity was detected in approximately half of the cases. In addition to the fact that different radiologists who do not have sufficient experience in this subject have performed ultrasonography, it is an undeniable fact that ultrasonography can only define gross lesions and FSA and histopathological analysis are the most significant methods to be trusted.

Tumor size in testicular tumors is one of the important criteria for malignancy. There is no definite cut-off value that is decided for size, but $20-25 \mathrm{~mm}$ is the generally accepted dimension in the literature (30). Carmignani et al. (15) showed that $80 \%$ of the masses smaller than $25 \mathrm{~mm}$ were benign. There are also small lesions with malignant pathology and large lesions with benign pathology in the literature $(30,31)$. Today, indications for radical orchiectomy have become more questionable. Paffenholz et al. (32) recently performed a retrospective, singlecenter analysis of 522 patients with primary testicular masses. The mean volume of benign tumors was significantly less than malignant tumors $\left(0.75 \mathrm{~cm}^{3}\right.$ vs $\left.15 \mathrm{~cm}^{3}\right)$ and a threshold value of $2.8 \mathrm{~cm}^{3}$ was predictive for malignancy. In addition, patients with benign tumors had longer symptom durations, their tumor markers were unchanged, and they had more fertility disorders or cryptorchidism. The authors concluded that early orchiectomy should be avoided in patients with these factors and should be considered more in favor of TSS.

In our series, there was a need for radical orchiectomy in a total of 6 patients. 4 cases were diagnosed as malign in FSA and underwent radical orchiectomy immediately after TSS, and 2 patients had surgical margin positivity and final pathology report consistent with malignancy (seminoma) and underwent radical orchiectomy in the follow-up period. Based on this data, it is likely that surgical margin positivity is a very important predictor of recurrence and that surgical margin positive cases should be closely followed. In the follow-up period, no distant metastases were detected and adjuvant treatment was not required in any of the patients. Many studies have shown good oncologic outcomes with TSS even in patients with a final malignant pathology $(30,31,33)$. If supported by prospective studies, TSS may be feasible for small, malignant masses in the future. However, we would like to point out that this method is not appropriate in cases with a mass which has strong suspicion of malignancy and a normal contralateral testis (12).

The crucial steps we took into account when performing this surgery were: clamping the cord immediately after inguinal exploration, revealing the tumor after tunica vaginalis and albuginea incision, and completely excising it together with its pseudocapsule, and sending one half of the sample to the FSA and the other half to the permanent pathological examination. We did not encounter any intraoperative or early postoperative complications due to our surgical technique.

\section{Study Limitations}

The limitations of our study were its retrospective nature, and inability not to have done a functional analysis of the remaining testis. A relatively small number of samples may also be a deficiency, but the number of cases is also limited in the existing publications on this subject in the literature. Also, we could not perform perioperative tumor bed biopsy. Because, in the reimbursement system of the social security institution in which this operation was involved, only once perioperative histopathological examination was allowed, and we used this option for FSA.

\section{Conclusion}

Our results suggest that TSS is a safe and effective surgical method for selected patients. In our opinion, males with a tumor in solitary testis or tumors in bilateral testes and for whom the fertility preservation is important, are suitable for this method. The status of the contralateral testis, size and ultrasound image of the mass, tumor markers, FSA outcome, age and expectations of the patient in the postoperative period, are 
critical determinant factors to make a decision between radical orchiectomy and TSS. Prospective, randomized trials are needed to routinely recommend TSS to patients with a small testicular mass and normal contralateral testis.

\section{Ethics}

Ethics Committee Approval: This is a retrospective study.

Informed Consent: All patients had given written informed consent before the surgery for giving permission for the use of the collected data at any time.

Peer-review: Externally peer-reviewed.

\section{Authorship Contributions}

Concept: F.K., B.S., Design: F.K., B.S., Data Collection and/or Processing: F.K., S.K., A.Ş., H.J.A., B.S., S.Ş., Ç.Ç., i.C., Analysis and/ or Interpretation: F.K., A.Ş., H.J.A., B.S., S.Ş., Literature Research: F.K., A.Ş., B.S., Writing: F.K.

Conflict of Interest: No conflict of interest was declared by the authors.

Financial Disclosure: No financial support.

\section{References}

1. Rosen A, Jayram G, Drazer M, Eggener SE. Global trends in testicular cancer incidence and mortality. Eur Urol 2011;60:374-379.

2. Nigam M, Aschebrook-Kilfoy B, Shikanov S, Eggener S. Increasing incidence of testicular cancer in the United States and Europe between 1992 and 2009. World J Urol 2015;33:623-631.

3. Che M, Tamboli P, Ro JY, Park DS, Ro JS, Amato RJ, Ayala AG. Bilateral testicular germ cell tumors: twenty-year experience at M.D. Anderson Cancer Center. Cancer-Am Cancer Soc 2002;95:1228-1233.

4. Heidenreich A, Hofmann R. Quality-of-life issues in the treatment of testicular cancer. World J Urol 1999;17:230-238.

5. Bojanic N, Bumbasirevic U, Bojanic G, Vukovic I, Milojevic B, Pekmezovic T. Testis sparing surgery for treatment of small testicular lesions: Is it feasible even in germ cell tumors? J Surg Oncol 2017;115:287-290.

6. Giannarini G, Mogorovich A, Bardelli I, Manassero F, Selli C. Testis-sparing surgery for benign and malignant tumors: A critical analysis of the literature. Indian J Urol 2008;24:467-474.

7. Seppelt U. Enukleation eines sukzessiven Zweittumors im Resthoden. Therapiewoche 1982;32:560-563.

8. Richie J. Simultaneous bilateral tumors with unorthodox management. World J Urol 1984;2:74.

9. Horstman WG, Haluszka MM, Burkhard TK. Management of testicular masses incidentally discovered by ultrasound. J Urol 1994;151:1263-1265.

10. Heidenreich A, Bonfig $R$, Derschum W, von Vietsch $H$, Wilbert DM. A conservative approach to bilateral testicular germ cell tumors. J Urol 1995;153:10-13.

11. Heidenreich $A$, Albers $P$, Krege $S$. Management of bilateral testicular germ cell tumours-experience of the German testicular cancer study group (GTCSG). European Urology Supplements 2006;5:97.
12. Albers P, Albrecht W, Algaba F, Bokemeyer C, Cohn-Cedermark G, Fizazi $\mathrm{K}$, Horwich $\mathrm{A}$, Laguna MP, European Association of U. [EAU guidelines on testicular cancer: 2011 update. European Association of Urology]. Actas Urol Esp 2012;36:127-145.

13. Yossepowitch 0 , Baniel J. Role of organ-sparing surgery in germ cell tumors of the testis. Urology 2004;63:421-427.

14. Steiner H, Holtl L, Maneschg C, Berger AP, Rogatsch H, Bartsch G, Hobisch A. Frozen section analysis-guided organ-sparing approach in testicular tumors: technique, feasibility, and long-term results. Urology 2003;62:508-513.

15. Carmignani L, Gadda F, Gazzano G, Nerva F, Mancini M, Ferruti M, Bulfamante G, Bosari S, Coggi G, Rocco F, Colpi GM. High incidence of benign testicular neoplasms diagnosed by ultrasound. J Urol 2003;170:1783-1786.

16. Ferreira U, Netto Junior NR, Esteves SC, Rivero MA, Schirren C. Comparative study of the fertility potential of men with only one testis. Scand J Urol Nephrol 1991;25:255-259.

17. Arai $Y$, Kawakita $M, O k a d a ~ Y$, Yoshida 0 . Sexuality and fertility in long-term survivors of testicular cancer. J Clin Oncol 1997;15:1444-1448.

18. Albers $P$, Albrecht $W$, Algaba F, Bokemeyer $C$, Cohn-Cedermark G, Fizazi $K$ Horwich A, Laguna MP, Nicolai N, Oldenburg J, European Association of U. Guidelines on Testicular Cancer: 2015 Update. Eur Urol 2015;68:1054-1068.

19. Heidenreich A, Höltl W, Albrecht W, Pont J, Engelmann U. Testis-preserving surgery in bilateral testicular germ cell tumours. Bju Int 1997;79:253-257.

20. Schmoll HJ, Souchon R, Krege S, Albers P, Beyer J, Kollmannsberger $C$, Fossa SD, Skakkebaek NE, de Wit R, Fizazi K, Droz JP, Pizzocaro G, Daugaard G, de Mulder PH, Horwich A, Oliver T, Huddart R, Rosti G, Paz Ares L, Pont O, Hartmann JT, Aass N, Algaba F, Bamberg M, Bodrogi I, Bokemeyer C, Classen J, Clemm S, Culine S, de Wit M, Derigs HG, Dieckmann KP, Flasshove M, Garcia del Muro X, Gerl A, Germa-Lluch JR, Hartmann M, Heidenreich A, Hoeltl W, Joffe J, Jones W, Kaiser G, Klepp 0, Kliesch S, Kisbenedek L, Koehrmann KU, Kuczyk M, Laguna MP, Leiva O, Loy V, Mason MD, Mead GM, Mueller RP, Nicolai N, Oosterhof G0, Pottek T, Rick O, Schmidberger $H$, Sedlmayer F, Siegert W, Studer U, Tjulandin S, von der Maase H, Walz P, Weinknecht S, Weissbach L, Winter E, Wittekind C, European Germ Cell Cancer Consensus G. European consensus on diagnosis and treatment of germ cell cancer: a report of the European Germ Cell Cancer Consensus Group (EGCCCG). Ann Oncol 2004;15:1377-1399.

21. Dieckmann KP, Skakkebaek NE. Carcinoma in situ of the testis: review of biological and clinical features. Int J Cancer 1999;83:815-822.

22. Heidenreich A, Weissbach L, Holtl W, Albers P, Kliesch S, Kohrmann KU, KP DI, German Testicular Cancer Study G. Organ sparing surgery for malignant germ cell tumor of the testis. J Urol 2001;166:2161-2165.

23. Lawrentschuk N, Zuniga A, Grabowksi AC, Rendon RA, Jewett MA. Partial orchiectomy for presumed malignancy in patients with a solitary testis due to a prior germ cell tumor: a large North American experience. J Urol 2011;185:508-513.

24. Djaladat H. Organ-sparing surgery for testicular tumours. Curr Opin Urol 2015;25:116-120.

25. De Stefani $S$, Isgro G, Varca V, Pecchi A, Bianchi G, Carmignani G, Derchi $L E$, Micali $S$, Maccio L, Simonato A. Microsurgical testis-sparing surgery in small testicular masses: seven years retrospective management and results. Urology 2012;79:858-862.

26. Silverio PC, Schoofs F, Iselin CE, Tille JC. Fourteen-year experience with the intraoperative frozen section examination of testicular lesion in a tertiary university center. Ann Diagn Pathol 2015;19:99-102.

27. Connolly SS, D'Arcy FT, Bredin HC, Callaghan J, Corcoran MO. Value of frozen section analysis with suspected testicular malignancy. Urology 2006;67:162-165.

28. Elert A, Olbert $P$, Hegele $A$, Barth $P$, Hofmann $R$, Heidenreich A. Accuracy of frozen section examination of testicular tumors of uncertain origin. Eur Urol 2002;41:290-293. 
29. Leroy $X$, Rigot JM, Aubert S, Ballereau C, Gosselin B. Value of frozen section examination for the management of nonpalpable incidental testicular tumors. Eur Urol 2003;44:458-460.

30. Gentile G, Brunocilla E, Franceschelli A, Schiavina R, Pultrone C, Borghesi $M$, Romagnoli $D$, Cevenini $M$, Dababneh $H$, Corcioni B. Can testis-sparing surgery for small testicular masses be considered a valid alternative to radical orchiectomy? A prospective single-center study. Clinical genitourinary cancer 2013;11:522-526.
31. Shilo Y, Zisman A, Raz O, Lang E, Strauss S, Sandbank J, Segal M, Siegel $\mathrm{YI}$, Leibovici D. Testicular sparing surgery for small masses. Urol Oncol 2012;30:188-191.

32. Paffenholz P, Held L, Loosen SH, Pfister D, Heidenreich A. Testis Sparing Surgery for Benign Testicular Masses: Diagnostics and Therapeutic Approaches. J Urol 2018;200:353-360.

33. Muller T, Gozzi C, Akkad T, Pallwein L, Bartsch G, Steiner H. Management of incidental impalpable intratesticular masses of $<$ or $=5 \mathrm{~mm}$ in diameter. Bju Int 2006;98:1001-1004. 